\title{
EDITORIAL
}

\section{O bstructive Sleep Apnea, Metabolic Syndrome, and Implications For Cardio-Vascular Diseases}

\author{
J. C. Suri \\ Department of Pulmonary, Critical Care \& Sleep Medicine, \\ Vardhman Mahavir Medical College \& Safdarjang Hospital, New Delhi
}

Indian J Sleep Med 2006; 1.3, 121-124

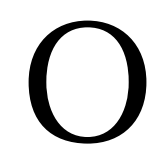
bstructive sleep apnea (OSA) affects about $4 \%$ of men and $2 \%$ women of middle aged population, as defined by an apnea-hypopnea index (AH I) $\geq 5$ and daytime excessive sleepiness (1). It has been frequently associated with increased cardiovascular morbidity and mortality from both ischemic heart disease and stroke $(2,3)$. D ata from many studies have identified a number of risk factors, such as hypertension, glucose intolerance, hypercholesterolemia (4) and increased neck circumference (5), which are independently associated with increased cardiovascular morbidity and mortality. Epidemiological studies have identified clustering of many such risk factors in individual patients and one such cluster which includes systemic hypertension, insulin resistance, hyperlipidemia and central obesity has been defined as "Syndrome X" (6). M ore recently, "T he N ational Cholesterol Education Program (N CEP)" adult treatment Panel III (ATP III) (2001) has identified a "constellation of lipid and non lipid risk factors of metabolic origin" and they have designated this cluster of abnormalities as the "metabolic syndrome" and also suggested that this syndromeisclosely linked to insulin resistance (7). According to the recommendations of this panel, the diagnosis of metabolic syndrome should be made when an individual has three of the following five risk factors: increased waist circumference $(>102 \mathrm{~cm}$ in men $\&>88 \mathrm{cms}$ in women), hypertension ( $\geq 130 / \geq 85 \mathrm{~mm} \mathrm{H} \mathrm{g}$ ), fasting

Address for correspondence:

\section{Dr. J. C. Suri}

Senior Chest Physician \& Head

Department of Pulmonary, Critical Care \& Sleep Medicine, Vardhman Mahavir Medical College \& Safdarjang Hospital, New Delhi

jcsurijc@del3.vsnl.net.in glucose of $\geq 110 \mathrm{mg} / \mathrm{dL}$, decreased high density lipoproteins (H DL) cholesterol ( $<40 \mathrm{mg} / \mathrm{dL}$ in $\mathrm{men} \&<$ $50 \mathrm{mg} / \mathrm{dL}$ in women) and triglycerides $\geq 150 \mathrm{mg} / \mathrm{dL}$. Besides these other abnormalities such as increased sympathetic activity, hypercoagulability, endothelial dysfunctions, increased markers of inflammation e.g. $\mathrm{C}$-reactive protein (CRP) and sedentary life- style are also important features of metabolic syndrome (8). A number of positive adverse interactions between these risk factors further increase the cardio vascular risk to the individual.

Patients with OSA have many cardiovascular risk factors commonly seen in individuals with metabolic syndrome. OSA is commonly associated with systemic hypertension independent of age, obesity, or other confounding factors as shown by various population based epidemiological studies $(9,10,11)$. Laboratory studies of animal models of OSA in dogs and rats strongly support the evidence that sustained hypertension can be caused by exposure to repeated episodes of obstructive apneas during sleep $(12,13)$. OSA is commonly observed in patients with difficult to control hypertension $(14,15)$. M oreover, treatment of OSA with nasal CPAP or tracheostomy has been associated with reduction in blood pressure (16). 0 besity is common in O SA patients $(17,18)$ and the reverse is also true i.e. the prevalence of OSA increases with increasing body mass index (BMI). The distribution of fat is mainly central resulting in an increase in waist and neck circumference. Whether OSA is caused by or results in central obesity is not fully understood. This is particularly important because central obesity is commonly seen in patients with insulin resistant diabetes. OSA is usually associated with conditions known to increase insulin-resistance and cardio-vascular risk, such as hypertension, obesity and

Indian Journal of Sleep M edicine (IJSM ), Vol. 1, N o. 3, 2006 
diabetes. Previously it was thought that increased insulin resistance in OSA patients is due to these co-existing conditions. Recently, a number of studies have demonstrated abnormal glucose-tolerance and hyper insulinemia in patients with OSA $(19,20)$ and, significantly increased insulin resistance in obese patients with OSA than patients with simple obesity $(21,22)$. Treatment of OSA with nasal continuous positive airway pressure (nCPAP) has been shown to significantly improve insulin sensitivity in these patients $(23,24,25)$. These data suggest that OSA causes insulin resistance independent of the effects of co-existent of central obesity. Patients with OSA have also been independently found to have other important features of metabolic syndrome including increased sympathetic activity $(26,27)$ which improves after treatment with CPAP (28); endothelial dysfunction (32,33), hyper coagulability $(29,30,31)$ and increased inflammation $(34,35)$. The latter abnormalities have also been shown to improve after treatment with nasal CPAP. Keeping in view the frequent occurrence of various components of metabolic syndromein patients with OSA, it has been suggested that metabolic syndrome (previously named 'Syndrome X') should include OSA as its integral component ('Syndrome Z') (36).

Although the previous studies have shown increased prevalence of individual components of metabolic syndrome, a recent study by Coughlin and colleagues (37) have demonstrated $40 \%$ increase in prevalence of metabolic syndrome in patients with OSA. This may help explain the increased cardio-vascular morbidity and mortality associated with OSA $(38,39)$. In a recent study by Shiina and colleagues (40), there was a significantly greater increase in pulse wave velocity (PW V) and Creactive proteins (CRP), both of which are known markers of cardiovascular risk, in patients with OSA and metabolic syndrome. Thus the concurrent presence of metabolic syndrome ('Syndrome Z') may increase the cardiovascular risk in subjects with OSA (40). This leads to an important question: whether treatment of OSA patients with nasal CPAP would lower the overall prevalence of the metabolic syndromeand the consequent cardiovascular risk? A significant insight has been provided by Milleron and colleagues (41) who have demonstrated that the treatment of OSA in coronary artery disease (CAD) patients is associated with a decrease in the occurrence of new cardiovascular events, and an increase in the time to such events. Although the study had limitations in methodology (sleep was not recorded), the number of patients and cardiovascular outcome variables used, nevertheless the findings have potentially important implications for cardiovascular disease prevention. The mechanisms by which CPAP acts to reduce the cardiovascular morbidity could be due to its cumulative effects on blood pressure, sympathetic activity and insulin resistance as al ready mentioned.

\section{Condusion}

O bstructive sleep apnea is independently associated with increased prevalence of various cardiovascular risk factors and as a cluster of abnormalities in the form of metabolic syndrome. Because of these risk factors, there is evidence that untreated OSA is associated with increased cardiovascular morbidity and mortality and poor long term prognosis. There is also evidence that treatment of OSA with nasal CPAP in CAD patients is associated with decreased hospitalization for heart failure, acute coronary syndrome and cardio vascular deaths. At this point of time, the majority of patients with OSA are treated because of symptoms such as excessive daytime sleepiness, snoring and poor quality of life. With the linking of OSA independently with metabolic syndrome and its consequent cardiovascular implications, the indications for treatment of OSA in future may need to be changed from symptomatic to prognostic reasons. Given the magnitude of obesity increasing to epidemic proportions, the prevalence of metabolic syndrome and OSA could also rise in future. This would have a tremendous impact on future cardiovascular morbidity and mortality and is likely to pose a great challenge for sleep specialists in the developing countries like India.

\section{References}

1. Young T, Palta M, Dempsey J et al. The occurrence of sleep disordered breathing among middle-aged adults. N Engl J Med 1993;328(17):1230-5.

2. Shahar E, Whitney C, Redline $\mathrm{S}$ et al. Sleep-disordered breathing and cardiovascular disease: cross-sectional results of the Sleep Heart Health Study. Am J Respir Crit Care Med 2001;163(1):19-25.

3. Shamsuzzaman AS, Gersh BJ, Somers VK. Obstructive sleep apnea: implications for cardiac and vascular disease JAMA. 2003;290:1906-1914.

4. Kannel WB. Some lessons in cardiovascular epidemiology from Framingham. Am J Cardiol 1976;37:269-82.

5. Larssen B, Svardstudd K, Welin L, et al. Abdominal adipose tissue distribution, obesity and the risk of cardiovascular diseases and death: 13 year follow up of the men born in 
1913.BMJ 1984;288:1401-4.

6. Reaven GM: Role of insulin resistance in human disease. Diabetes 1988;37:1595-607.

7. Executive summary of the third report of the national cholesterol education program (NCEP) expert panel on detection, evaluation, and treatment of high blood cholesterol in adults (adult treatment panel III). JAM A. 2001;285: 2846 2497.

8. Reaven G. Metabolic syndrome. Pathophysiology and implications for management of cardiovascular disease. Circulation. 2002;106:286-288.

9. Nieto FJ, Young TB, Lind BK, Shahar E, Samet JM, Redline S, D'Agostino RB, N ewman AB, Lebowitz MD, Pickering TG . Association of sleep-disordered breathing, sleep apnea, and hypertension in a large community-based study. Sleep Heart Health Study. JAMA 2000;283:1829-1836.

10. Young T, Peppard P, Palta M, Hla KM, Finn L, Morgan B, Skatrud J. Population-based study of sleep-disordered breathing as a risk factor for hypertension. Arch Intern Med 1997;157:1746-1752.

11. Peppard PE, Young T, Palta M, Skatrud J. Prospective study of the association between sleep-disordered breathing and hypertension. N EnglJ Med 2000;342:1378-1384.

12. Brooks D, Horner RL, Kozar LF, Render-Teixeira CL, Phillipson EA. Obstructive sleep apnea as a cause of systemic hypertension. Evidence from a canine model. J Clin Invest 1997;99:106-109.

13. Bao G, Metreveli N, Fletcher EC. Acute and chronic blood pressure response to recurrent acoustic arousal in rats. Am J Hypertens 1999;12:504-510.

14. Grote L, Hedner J, Peter JH. Sleep-related breathing disorder is an independent risk factor for uncontrolled hypertension. J Hypertens 2000;18:679-685.

15. Logan AG, Tkacova R, Tisler A, Leung RS, Fitzgerald FS, Bradley TD. High prevalence of obstructive sleep apnea in refractory hypertension. J Hypertension 2001. (In press)

16. Logan AG, Tkacova R, Perlikowski SM, Leung RS, Tisler A, Floras JS, Bradley TD. Effects of continuous positive airway pressure on blood pressure in refractory hypertensive patients with sleep apnea. J Hypertens 2001. (In press).

17. Levinson PD, McGarvey ST, Carlisle CC, et al. Adiposity and cardiovascular risk factors in men with obstructive sleep apnea. Chest 1993;103:1336-42.

18. Grunstein RR, Wilcox I, Yang TS, et al. Snoring and sleep apnea in men: interaction with central obesity and hypertension. Int J O besity 1993;17:533-40

19. Strohl KP, Novak RD, Singer $W$, et al. Insulin levels, blood pressure and sleep apnea. Sleep 1994;17:614-8.

20. Brooks BA, Cistulli PA, Borkman M, et al. Effect of nasal continuous positive airway pressure treatment on insulin sensitivity in patients with type II diabetes and obstructive sleep apnea. J Clin Endocrinol M etab 1994;79:1681-5.

21. Obstructive sleep apnoea syndrome impairs inslulin sensitivity independently of anthropometric variables. Clin Endocrinol (oxf). 2003 Sep;59(3):374-9.
22. Harsch IA, Hahn EG, Konturek PC. Insulin resistance and other metabolic aspects of the obstructive sleep apnea syndrome. Med Sci Monit, 2005 Mar;11 (3):RA70-5.

23. Ip M, Lam B, Ng M et al. Obstructive sleep apnoea is independently associated with insulin resistance. Am J Respir Crit Care Med 2002;165:670-6.

24. Punjabi N, Sorkin J, Katzel L et al. Sleep-disordered breathing and insulin resistance in middle-aged and overweight men. Am J Respir Crit Care Med 2002;165(5):677-82.

25. Harsch IA, Pour Schahin S, Radespiel-Troger M et al. CPAP treatment rapidly improves insulin sensitivity in patients with OSAS. Am. J. Respir. Crit. Care Med. 2003.

26. Somers VK, Dyken ME, Clary MP, Abboud FM. Sympathetic neural mechanisms in obstructive sleep apnea. J Clin Invest 1995:96:1897-1904.

27. Hedner J, Ejnell H, Sellgren J, Hedner T, Wallin G. Is high and fluctuating muscle nerve sympathetic activity in the sleep apnoea syndrome of pathogenetic importance for the development of hypertension? J Hypertens Suppl 1988:6:S529-S531.

28. Narkiewicz K, Masahiko Kato, Bradley G. Phillips,; Catherine A. Pesek, DO; Diane E. Davison, RN, MA; Virend K. Somers. N octurnal Continuous Positive Airway Pressure Decreases Daytime Sympathetic Traffic in O bstructive Sleep Apnea Circulation. 1999;100:2332-2335.

29. Sanner BM, Konermann M, Tepel M, GroetzJ, Mummenhoff C, Zidek W. Platelet function in patients with obstructive sleep apnoea syndrome. Eur Respir J 2000;16:648-652.

30. Bokinsky G, Miller M, Ault K, Husband P, Mitchell J. Spontaneous platelet activation and aggregation during obstructive sleep apnea and its response to therapy with nasal continuous positive airway pressure. A preliminary investigation. Chest 1995;108:625-630.

31. Chin K, O hi M, Kita H, Noguchi T, Otsuka N, Tsuboi T, Mishima M, Kuno K. Effects of N CPAP therapy on fibrinogen levels in obstructive sleep apnea syndrome. Am J Respir Crit Care Med 1996;153: 1972-1976.

32. Faller DV. Endothelial cell responses to hypoxic stress. Clin Exp Pharmacol Physiol 1999;26:74-84.

33. Schulz R, Mahmoudi S, Hattar K, Sibelius U, O Ischewski H, Mayer K, Seeger W, Grimminger F. Enhanced release of superoxide from polymorphonuclear neutrophils in obstructive sleep apnea. Impact of continuous positive airway pressure therapy. Am J Respir Crit Care Med 2000;162:566570

34. Teramota S, Yamamota $\mathrm{H}, \mathrm{O}$ uchi $\mathrm{Y}$. Increased $\mathrm{C}$-reactive protein and increased plasma interleukin- 6 may synergistically affect the progression of coronary atherosclerosis in obstructive sleep apnea syndrome [letter]. Circulation 2003;107, E40.

35. Alexandros $\mathbf{N}$, Vgontzas, Dimitris A, et al. Sleep apnea and daytime sleepiness and fatigue: relation to visceral obesity, insulin resistance, and hypercytokinemia. J Clin Endocrinol Metab 2000;85,1151-1158.

36. Wilcox I, mc Namara SG, Collins FL et al. "Syndrome Z". the interaction of sleep apnoea, vascular risk factors and

Indian Journal of Sleep M edicine (IJSM ), Vol. 1, N o. 3, 2006 
heart disease. Thorax. 1998:53 (Suppl 3) S25-S28.

37. Coughlin S., Lynn Mawdsley, Julie A. Mugarza, Peter M. A. Calverley, John P. H. Wilding. O bstructive sleep apnoea is independently associated with an increased prevalence of metabolic syndrome. European Heart Journal (2004) 25, 735-741.

38. Mooe T, Franklin $\mathrm{KA}$, Holmstrom $\mathrm{K}$ et al. Sleep-disordered breathing and coronary artery disease: long-term prognosis. Am. J. Respir. Crit. Care Med. 2001;164:1910-1913.

39. Peker $\mathbf{Y}$, hedner J, Kraiczi $\mathrm{H}$ et al. Respiratory disturbance index: an independent predictor of mortality I coronary artery disease. Am. J. Respir. Crit. Care Med. 2000;162:81-86.

40. Shiina K, Tomiyama H, Takata $Y$, Usui $Y$ et al. concurrent presence of metabolic syndrome in obstructive sleep apnea syndrome exacerbataes the cardiovascular risk: a sleep clinic cohort study. Hypertens REs. 2006 J un;29 (6):433-41.

41. Olivier Millerona, Remy Pilli_erea, Arlette Foucherb, Florence de Roquefeuila, Philippe Aegerterc, Guillaume Jondeaua, Bernadette G. Raffestinb, Olivier Dubourga Benefits of obstructive sleep apnoea treatment in coronary artery disease: a long-term follow-up study. European Heart Journal 2004; 25: 728-734 